\title{
Re-thinking instructional strategies for enhancing gender equity in learning primary science: let's try cooperative small group instructional mode
}

\author{
Uyoata $^{17}$, U. E., Ekpo ${ }^{18}$, K., Ibe ${ }^{19}$, J. and Okon ${ }^{20}$, A.
}

\begin{abstract}
The study investigated the effect of cooperative small group instructional mode on the cognitive achievement of boys and girls in primary science. Eighty-two pupils (41 girls and 41 boys) were drawn from 2 randomly selected primary schools and from 2 intact primary 5 classes in Uyo Local Government Education Authority. The subjects were exposed to 5 weeks of instruction in selected science concepts from primary 5 curriculum module. Two modes of instruction used were the cooperative small group and the whole class instructional modes. Instrument for collecting the data was the Primary Science Achievement Test (PSAT). Data analysis involved the use of t-test statistic. Results revealed no statistically significant difference in the achievement of boys and girls in primary science. The paper claims that cooperative small group instructional mode could remove gender bias in female pupils' achievement in science.
\end{abstract}

Keywords cooperative small group instruction, gender bias in achievement, science achievement

\section{Introduction}

Gender is a term used in describing the behaviour and character traits expected of persons on the basis of being born either a male or a female. According to Bassow (1991), the society sort of views certain activities as gender-typed. In this way, some problem-solving skills and subjects are arrogated to males while others are said to be female-dominated. Gender stereotype is very much observed among Africans. Right from birth, the African child is restricted to the role expectations approved by the society. As a result of this cultural practice, girls have been discouraged from developing their individual potentials in various ways and disciplines. Azikiwe (1998), explains further that as a result of sex-typing, many girls have been deterred from striving to develop their individual potentials because they have to accept the roles forced on them for them to belong and be accepted in the society. The girl-child faces a dilemma especially when she tries to venture into those areas culturally regarded as a "male reserved area" (MRA). Until recently science, mathematics, and technology were such MRAs in the school curriculum. A girl-child who was not successful in these areas may either be satisfying a self-fulfilling prophecy, after all, her gender was not expected to do well in them,

\footnotetext{
${ }^{17}$ Udo E. Uyoata (Ph.D) lectures at the Faculty of Education, University of Uyo, Nigeria. Email: doctoruyoata@yahoo.com

${ }^{18}$ Koko Ekpo (Ph.D) lectures at the Faculty of Education, Cross River University of Technology, Calabar Campus, Nigeria.Emaildrkokoe@yaho.com.

19 James Ibe lectures at the Faculty of Education, Cross River University of Technology, Calabar Campus, Nigeria.

${ }^{20}$ Akpan Okon (Ph.D) lectures at the Faculty of Education, Cross River University of Technology, , Calabar Campus, Nigeria.
} 
or her efforts towards success might have been frustrated through exposure to a restrictive educational environment and poor methods of teaching.

However, the changing times, events and circumstances are continually modifying negative opinions about the female gender. For example, in socio-political endeavours, economic empowerment, and educational attainments, the females sort of share equal opportunities with their male counterparts. Nevertheless, there is a preponderance of the males leading in many endeavours of life including science and technology.

Studies on gender difference in social achievement are inconclusive. Gardner (1985) contended that gender is not a relevant factor to be associated with school achievement. Research findings as reported by Oyesoji (1999) showed that male subjects achieved higher scores than the female in their academic performance. Wozencraft (1963) found a superior school achievement in favour of girls, whereas, Iniomiesa (1989), Yilwa and Olarinoye (2004) found no significant difference in the performance of male and female subjects in science process skills.

The various results of research studies lend credence to the fact that issue of gender on pupils' performance in various subjects in the school curriculum is still debatable. As educators, our concern should be on rethinking ways of establishing equity between the male and female in all areas of learning including what had been conceived to be "reserved areas of the curriculum for either the females or the males.

Current science education innovations and curriculum reviews have proposed a re-thinking of several common-ground scenic process goals which if they are adopted and followed carefully should enable all students to experience success in science, irrespective of gender. Some of these innovations are interventions through instructional strategies. Danmole (1998) had said that consensus opinion by reformers point to the fact that more hands-on activities be used in science preferably, in a cooperative learning situation and that girls are known to benefit from such instructional strategies. He further suggested that a total science curriculum should be made personally meaningful to the learners through the use of heterogeneous and cooperative groups to promote high level participation among learners.

Okwo (2001) suggested copious use of instructional materials during teaching. According to him, since instructional materials facilitate instruction, it stands to reason that in the absence of sexism in instructional materials, they are expected to bridge the gender gap in achievement in mathematics. The same gap in science might also be bridged using gender-neutral instructional materials.

Gandu (2004) suggested that gender stereotypes can be broken by group/team work through sharing of responsibilities. He said further that groups should be formed with female and male children handling different assignments and projects together. Similarly, Ayotola (1999) reviewing several researches on gender-bridging methodologies said that perhaps innovative instructional techniques that present challenging tasks, yet prevent undue competition in an ego-oriented atmosphere will contribute to a more advantageous learning situation for girls. Such instructional technique may mean the use of cooperative small group instructional mode.

Cooperative learning, according to Sadler (1974) implies that children sit in groups where they can help each other and work together. Cooperative instructional mode is an aspect of learning by inquiry and discovery. Terwell (1999) has shown that learning depends in part on the nature of students' participation in interaction process. Students learn more by giving and receiving elaborate help to and from others within the class as a social system. In this kind of classroom, students become interdependent as it happens in real life situation. Johnson and Johnson (1983) said that having students work together cooperatively is more powerful than 
having them to work alone competitively or individually. Ayotola (1999) therefore suggested strongly that instructional strategies which involve cooperation should be selected for instruction in Science, Technology and Mathematics (STM), that such strategies could be useful for teaching so as to remove gender bias in STM.

The typical classroom interaction profile is teacher-dominated and the dominant instructional strategy used by many teachers is whole -class lecture method. As noted by Okebukola (2002) the peer culture of the classroom remains relatively unexplored and that the power of appropriate student/student interaction on a range of learning outcomes has been grossly underestimated. The apparent superiority of males over their female counterparts in science achievement (Ojerinde, 1998; Alamina, 2001; Ekeh, 2004) may have been caused by poor instructional strategy which warrants a rethinking of the way in which children are taught science in the primary schools.

The purpose of the study was to investigate if cooperative small group instructional mode could bridge the gap between male and female pupils in their science achievement. The study focused on the following questions:

1. Is there any difference in the science achievement of primary school pupils exposed to cooperative small group instructional mode and those exposed to conventional whole class instructional mode?

2. Is there any difference in the science achievement of male and female pupils exposed to cooperative small group instructional mode?

The following hypotheses were formulated based on the research questions raised:

1. There is no significant difference in the science achievement of pupils exposed to cooperative small group instructional mode and those exposed to whole class instructional mode.

2. There is no significant difference in the science achievement of male and female pupils when exposed to cooperative small group instructional mode.

A quasi-experimental design using pre-test, post-test, non-randomized control group and intact classes was adopted for the study.

\section{Method}

The study was based in Uyo Local Educational Authority (LEA) on all primary 5 pupils in the 18 primary schools in the LEA. Purposive sampling and simple random sampling were used to select 2 schools from those that satisfied the criteria for the purpose of the study. One intact class was randomly selected from streams of primary 5 in each of the schools.

The two classes were randomly assigned to Experimental "E" and Control " $\mathrm{C}$ groups. There were 42 primary 5 pupils ( 21 males and 21 females) in the E group and 40 (20 males and 20 females) in the $\mathrm{C}$ group.

The instrument used for the study was the Primary Science Achievement Test (PSAT), drawn up by the researcher and based on the content of the primary science curriculum used in schools. PSAT consisted of 20 multiple-choice test items with 4 options. Reliability was secured using the Kuder - Richardson formula (K-R 20). It yielded a reliability coefficient of 0.81 .

Two science educators from the Department of science Education, University of Uyo and one from the Department of Primary Education Studies, in College of Education in Akwa Ibom State assessed the appropriateness of the items in terms of reading difficulty, clarity and 
vocabulary considering the level of pupils on which the test would be administered. The assessors' observations and suggestions were useful in drawing up the final version of the instrument.

Teachers in both the experimental and control groups were coordinated for 2 days before they started the actual teaching which lasted for 5 weeks. A total of 15 class periods were used; each class period lasted for 35 minutes. One class period was used for theoretical presentation while double periods were used for practical.

The experimental class was divided into 7 groups of 6 pupils each. There were equal distributions of male and female subjects in each group. The control group consisted of 20 males and 20 females. They were allowed to remain as a whole class.

The teachers taught their classes using 5 lesson plans on the concepts of air and heat energy which they had been exposed to during coordination. Both of them were male teachers and had NCE (Nigeria Certificate in Education) in Integrated Science. NCE is the basic qualification for teaching in Nigerian Primary schools. Pupils in the experimental class were exposed to lessons using cooperative small group instructional mode. The pupils remained in their groups for instruction and practical. They were encouraged to interact with one another freely. They were to discuss and share ideas but were to take personal note of observations and opinion reached by the group. Their work was however assessed individually using PSAT.

The whole class instructional class was taught mainly by lecture whereby, the teacher did most of the talking and the pupils merely listened. They were not given the opportunity to interact with one another. Discussions were very brief and teacher gave pupils some take-home assignments to do. At the end of the experiment, the class was examined through PSAT.

\section{Results}

The pre-test scores of both the $\mathrm{E}$ and $\mathrm{C}$ groups in Table 1 showed that there was no significant difference between the groups before the start of the experiments.

Table 1 t-test Comparison of pretest mean scores of $\mathbf{E}$ and $\mathbf{C}$ groups in PSAT

\begin{tabular}{|c|c|c|c|c|c|}
\hline Groups & $\mathbf{N}$ & $\bar{x}$ & SD & T-cal & T-crit \\
\hline Experimental & 42 & 7.40 & 1.59 & \multirow{2}{*}{$0.05 \mathrm{~ns}^{*}$} & \multirow{2}{*}{1.67} \\
\hline Control & 40 & 7.38 & 2.01 & & \\
\hline
\end{tabular}

The two groups were therefore comparable in their ability and knowledge of science before intervention.

Table 2 shows that there is a significant difference in the mean scores of experimental and control groups.

Table 2: Summary of t-test analysis on Post-test scores of $\mathbf{E}$ and $\mathrm{C}$ groups in PSAT

\begin{tabular}{lccccc}
\hline Groups & $\mathbf{N}$ & $\overline{\boldsymbol{x}}$ & SD & T-cal & T-crit \\
\hline Experimental & 42 & 11.52 & 1.98 & & \\
Control & 40 & 8.22 & 2.17 & & 2.00 \\
\hline
\end{tabular}

*significant, $\mathrm{t}(80)=7.23, \mathrm{p}<0.05$

This result leads to the rejection of hypothesis one. Pupils exposed to cooperative small group instructional mode performed better than those exposed to whole class instructional mode. 
Table 3 Summary of t-test analysis of Experimental group scores of male and female subjects in PSAT before experiment

\begin{tabular}{lccccc}
\hline Groups & $\mathbf{N}$ & $\overline{\boldsymbol{x}}$ & $\mathbf{S D}$ & T-cal & T-crit \\
\hline Male & 21 & 7.66 & 1.56 & & \\
Female & 21 & 6.71 & 2.19 & $5.25^{*}$ & 2.02 \\
\hline
\end{tabular}

*significant, $p<.05$

Result in Table 3 indicates that the mean achievement of the male subjects $(\bar{x}=7.66)$ is greater than that of the female subjects $(\bar{x}=6.71)$. Correspondingly, the calculated t-value of 5.25 is greater than the critical value of 2.02 at $\mathrm{p}<.05$. There is a significant difference in science achievement between the male and female subjects, prior to intervention. Hypothesis two was tested using the analysis in Table 4

Table 4 Summary of t-test analysis of Experimental group scores of male and female subjects in PSAT after experiment

\begin{tabular}{lccccc}
\hline Groups & $\mathbf{N}$ & \} & SD & T-cal & T-crit \\
\hline Male & 21 & 11.76 & 1.97 & & $1.21^{\mathrm{ns}}$ \\
Female & 21 & 11.52 & 2.20 & & 2.02 \\
\hline
\end{tabular}

Ns = not significant $p<.05$

The summary of the t-test in Table 4 shows $\mathrm{t}(40)=1.21$ at $\mathrm{p}<.05$. This $\mathrm{t}$-value is smaller than the critical t-value of 2.02; the result allows for the retention of hypothesis 2 . There is therefore no significant difference in the achievement of male and female subjects in science after intervention. This result therefore signifies that gender is not a significant factor in achievement in science.

\section{Discussion}

From the results of this study, it is seen that pupils who were exposed to cooperative small group instructional mode performed significantly better than those who were taught using the conventional whole class instructional mode. This result confirms those of earlier studies in other science subjects (Okebukola, 1984; Ojo, 1997).

The results also indicate that when both male and female subjects were exposed to cooperative small group instructional mode, the performance of the female subjects not only improved considerably but that at the end of the experiment, their mean scores were not significantly different from those of their male counterparts. The non-significant difference in the mean performance of male and female subjects confirms findings of Yilwa and Olarinoye (2004) who found that sex (gender) was not a significant factor in students' achievement in knowledge of science process skills. It however contradicts Ekeh (2004) who said that male primary school pupils are superior to their female counterparts in terms of science and mathematics achievement.

\section{Conclusion and recommendation}

Based on findings of this study, it can be said that learning and achievement in science are not gender bias. It is also reasonable to conclude that gender equity in science learning and 
achievement can be enhanced among primary school pupils by adopting an instructional strategy which allows children to work together as equals in small groups. When children are made to learn science cooperatively in small groups, reticent pupils tend to participate more than when they are members of the class as a whole. Children can enlist the help of others; share ideas, proffer solution to problems irrespective of gender and background.

Teachers should create collaborative learning situations in the classroom and encourage pupils to interact among themselves in small groups. Teachers should teach the pupils basic skills of interacting to enable them accommodate one another's differences. Okebukola (2002) advised in this respect, that teachers should 'mix' the class members in heterogeneous groups (male/female, handicapped or not, bright or struggling, or from different backgrounds) so that students get beyond their initial stereotypes and are able to treat others as "other science student" and fellow group members.

\section{References}

Alamina, J. I. (2001). An impediment to women in science: Cultural influence and the way forward. 42 ${ }^{\text {nd }}$ Annual Conference Proceedings of Science Teachers Association of Nigeria. Ibadan: STAN.

Ayotola, A. (1999). Strategies for improving the performance of female pupils in Mathematics. African Journal of Educational Research, $\underline{5}$ (1), 76-85

Azikiwe, U. (1998). A case for women studies in Nigerian primary secondary school curriculum. Nigerian Journal of Curriculum Studies, Special, 7-11.

Bassow, S. A (1991). Gender roles. In H. Therney (Ed), Women studies encyclopedia: Views from the science Vol. 11. New York: Peter Bedrock Books.

Danmole, B. T. (1998). Gender, location and type of school as predictors of science knowledge among fresh entrants into Junior Secondary Schools in Kwara State. Journals of Research in Education 2(2), 44-51.

Ekeh, P. U. (2004). Gender bias and achievement in science and mathematics among primary schools pupils: implication for human resource development. Nigerian Journal of Curriculum studies, 11(2), 30-33.

Gandu, G. D. (2004) Implementing gender sensitive curriculum for human resource development. The case of revised Nigerian languages curricula. Nigerian Journal of Curriculum Studies, 11(1), 215-220.

Gardner, P. L. (1985). Attitude to science: a review. Studies in Science Education. 1-4.

Inomiesa, E. A. (1989). Sex and School location as factor in science and student's achievement. Journal of Science Teacher's Association of Nigeria, 21(2), 117-125.

Johndon, F. E. \& Johnson, R. T. (1983). The socialization and achievement crises. Are cooperative learning experiences the solution? In L. Biekam (Ed), Applied Social Psychology. Beverly Hills, C. A: Sage Publications.

Ojerinde, D. (1998). Under achievement in schools science in Nigeria. African Journal of Education, 1(1),176-191.

Ojo, M. O. (1997). Which classroom environment engenders better performance among PrePrimary Pupils? Gombe Technical Education Journal, 1,21-24.

Okebukola, P. A. (1984). Tackling the problem of large classes in Biology. An investigation into effectiveness of cooperative learning technique. Journal of Science teachers Association of Nigeria, 22(2), 73-77. 
Okebukola, P. A. (2002). Beyond the stereotype to new trajectories in science teaching. Ibadan: STAN

Okwo, F. O. (2001). Effect of mock-up primary pupils achievement in "telling the Time" Nigerian Journal of Curriculum studies, $\underline{8}(1), 203-205$.

Oyesoji, A. A. (1999). Effects of gender and parenting style on academic performance of undergraduate students of a Nigerian university. African Journal of Education Research, $\underline{5}(1), 169-174$.

Sadler, J. E. (1974). Concept in Primary Education. London: George. Allen and Unwin.

Terwell, J. (1999). Constructivism and implication for curriculum theory and practice. Journal of Curriculum Studies. 31(2), 195-199

Wozencraft, (1963). Sex comparison of certain abilities. Journal of educational research, LVII. $21-27$.

Yilwa, A. V. \& Olarinoye, R. D (2004). The influence of location, proprietorship, sex and grade level on junior secondary schools students' performance in the skill of observing. Nigerian Journal of Curriculum Studies, 11,(1),54-63. 
